\title{
Pengaruh Produk, Harga dan Promosi terhadap Keputusan Pembelian Rumah pada Green Avina Birem Puntong Langsa Baro
}

\author{
Zikriatul Ulya Daud \\ Fakultas Ekonomi dan Bisnis Islam, IAIN Zawiyah Cot Kala Langsa \\ e-mail: zikriatululya@gmail.com
}

\begin{abstract}
Abstrak
Penelitian ini dilakukan dengan tujuan untuk mengetahui pengaruh produk, harga dan promosi secara parsial dan secara simultan terhadap keputusan pembelian rumah pada Green Avina Birem Puntong Langsa Baro. Penelitian ini menggunakan data primer yang bersumber dari 53 orang responden. Data dianalisis dengan menggunakan persamaan regresi linier berganda, koefisien determinasi $\left(R^{2}\right)$, uji $t$ dan uji $F$. Hasil penelitian menunjukkan bahwa hasil uji koefisien determinasi $\left(R^{2}\right)$ diperoleh Ajusted $R$ Square sebesar 42,3\% variabel produk, promosi dan harga memberikan pengaruh terhadap keputusan pembelian rumah pada Green Avina di Birem Puntong Langsa Baro dan sisanya sebesar $57,7 \%$ dipengaruhi variabel lain yang tidak masuk dalam penelitian ini seperti lokasi dan fasilitas. Hasil uji t menunjukkan bahwa secara parsial variabel produk, harga dan promosi berpengaruh signifikan terhadap keputusan pembelian rumah pada Green Avina Birem Puntong Langsa Baro. Hasil uji F menunjukkan bahwa secara simultan variabel produk, harga dan promosi berpengaruh signifikan terhadap keputusan pembelian rumah pada Green Avina Birem Puntong Langsa Baro.
\end{abstract}

Kata Kunci : Produk, Harga, Promosi dan Keputusan Pembeliam

\section{PENDAHULUAN}

Kota Langsa merupakan salah satu pemerintahan di Provinsi Aceh yang memiliki penduduk pada tahun 2014 sebanyak berada 162.544 jiwa yang meningkat dari tahun 2015 sebanyak 3.346 jiwa, menjadi sebanyak 165.890 jiwa (BPS Kota Langsa, 2016). Pertumbuhan penduduk yang meningkat dan diiringi dengan meningkatnya kebutuhan serta didukung dengan adanya kemampuan untuk membeli barang dengan kualitas dan nilai tambah yang semakin tinggi. Kondisi ini mendorong perusahaan berlomba-lomba semaksimal mungkin dalam melayani konsumen. Semakin kompleksnya permintaan konsumen menyebabkan timbulnya perusahaan baru yang bertujuan untuk memenuhi kebutuhan atau keinginan konsumen.

Setiap perusahaan melakukan penawaran produknya dengan keunggulan-keunggulan yang dimiliki oleh produk yang dihasilkannya. Oleh kerena itu memunculkan persaingan diantara perusahaan dengan produk yang sama atau sejenis menjadi semakin ketat karena konsumen akan memilih yang lebih baik. Dengan demikian maka perusahaan harus menjaga kelangsungan hidup. Perusahaan sebagai produsen harus lebih cermat dalam mengamati kebutuhan atau keinginan konsumen dan semakin siap dalam menghadapi pasar. Salah satu kesiapan yang dapat diperhatikan oleh perusahaan adalah bauran pemasaran.

Bauran pemasaran terdiri dari produk, harga, promosi dan tempat (Tjiptono, 2008). Bauran 
pemasaran ini digunakan untuk pengembangan program pemasaran untuk menyesuaikan selera konsumen, dengan harapan agar konsumen merasa puas atas produk dan jasa yang telah ditawarkan. Produk yang ditawarkan oleh produsen kepada konsumen yang perlu diperhatikan adalah kualitasnya, karena konsumen membeli produk untuk digunakan selalu memperhatikan kualitas. Selain itu harga produk yang ditawarkan kepada konsumen juga menjadi pertimbangan, bila harga rendah atau tinggi harus disesuaikan dengan kualitas dari produk. Bila produk dan harga sudah sesuai maka yang perlu diperhatikan lagi oleh produsen adalah promosi yaitu memperkenalkan produk kepada konsumen. Selanjutnya pihak perusahaan perlu mengetahui akan kebutuhan dan keinginan konsumen terutama pada produk kebutuhan dasar seperti salah satunya adalah rumah.

Rumah merupakan tempat tinggal yang menjadi salah satu kebutuhan pokok manusia selain pakaian dan makanan. Setiap manusia membutuhkan rumah untuk tempat berlindung dan sebagai tempat berkumpul dan berlangsungnya aktivitas keluarga, sekaligus rumah sebagai sarana investasi. Fungsi rumah juga telah berubah, dari yang semula hanya sekedar sebagai tempat berlindung, kini sebuah rumah tak cukup hanya untuk berteduh namun juga dituntut dapat mengakomodir kebutuhan dan keinginan pemiliknya. Seperti lokasi yang stategis, bangunan yang bagus \& kokoh, dan lingkungannya yang nyaman. Dengan kata lain tak cukup hanya asal untuk berteduh namun juga harus bisa menjadi tempat tinggal yang layak (Susilawati, 2014). Untuk itu pihak perusahaan dalam hal ini develover perumahan perlu memperhatikan kualitas produk dan harga serta melakukan promosi untuk memberi informasi kepada calon pembeli rumah.

Green Avina merupakan perumahan yang berlokasi di Gampong Birem Puntong Kecamatan Langsa Baro. Perumahan ini merupakan perumahan yang dibangun oleh PT. Avina Semesta Raya Group dengan rumah type 36 dan type 45 yang disubsidi oleh Pemerintah melalui Kementerian Perumahan Rakyat. Pada saat penelitian ini dilakukan, perumahan Green Avina yang sudah siap huni sebanyak 120 unit dan yang telah dihuni sebanyak 53 unit. Berdasarkan hasil penelitian pendahuluan kepada 5 orang penghuni perumahan Green Avina diketahui bahwa rumah yang disediakan hanya dua jenis yaitu type 36 dan type 45 , sehingga hanya terdapat dua pilihan saja. Rumah yang mereka peroleh memiliki kualitas yang baik tetapi masih terdapat beberapa kekurangan seperti pada saat menerima rumah, cat tembok rumah yang masih tipis serta masih terdapatnya rumah yang atapnya bocor. Bagian bangunan seperti pintu yang tidak bisa dikunci akibat pintu pada saat pemasangan tidak tepat pada posisinya.

Harga rumah type 36 dan 45 ini rumah rumah bersubsidi pemerintah sehingga harganya adalah harga yang terjangkau dan harga tersebut tertera pada daftar harga pada PT. Avina Semesta Raya Group. Harga yang ditawarkan kurang sesuai dengan harga yang ditetapkan, sehingga pada saat melakukan pembayaran lebih dari harga pada daftar harga, baik pembayaran dilakukan secara tunai maupun secara angsuran. Perbedaan harga tersebut menurut pembeli dikarenakan adanya kelebihan luas lahan perumahan sehingga harus dibayar melebihi harga yang tertera di brosur. Bagi konsumen 
yang membeli secara kredit, harus membayar biaya tambahan seperti biaya pemesanan rumah, biaya akad dan biaya pembuatan surat tanah. Hal tersebut diluar dugaan dari konsumen sehingga harus menyiapkan uang selain yang ditetapkan dari daftar tersebut. Promosi yang dilakukan oleh pihak PT. Avina Semesta Raya Group hanya berupa pemberian brosur kepada konsumen calon pembeli perumahan dan melakukan penjualan langsung dengan memberikan informasi kepada calon pembeli serta penjualan dari mulut ke mulut konsumen yang sudah membeli. Penelitian ini dilakukan dengan tujuan untuk mengetahui pengaruh produk, harga dan promosi secara parsial dan secara simultan terhadap keputusan pembelian rumah pada Green Avina Birem Puntong Langsa Baro.

\section{TINJAUAN PUSTAKA}

\section{Produk}

Kotler dan Armstrong (2008) menyatakan bahwa produk adalah segala sesuatu yang dapat ditawarkan ke pasar untuk mendapatkan perhatian, dibeli, digunakan, atau dikonsumsi yang dapat memuaskan keinginan atau kebutuhan. Selanjutnya, menurut Alma (2010), produk merupakan seperangkat atribut baik berwujud maupun tidak berwujud, termasuk di dalamnya masalah warna, harga, nama baik pabrik, nama baik toko yang menjual (pengecer), dan pelayanan pabrik serta pelayanan pengecer yang diterima oleh pembeli guna memuaskan keinginannya.

\section{Indikator Produk}

Menurut Kotler dan Amstrong (2008), indikator dari produk terdiri dari:

1. Keanekaragaman produk (produk variety)

2. Kualitas produk (quality)

3. Rancangan produk (design)

4. Ciri-ciri produk (features)

5. Merek produk (brand name)

6. Kemasan produk (packaging)

7. Tingkat pelayanan (service)

8. Garansi (warranties)

9. Ukuran produk (size)

10. Pengembalian (return)

\section{Harga}

Menurut Kotler dan Keller (2007), harga adalah jumlah uang yang harus dibayar pembeli untuk memperoleh produk. Harga merupakan unsur terpenting kedua dalam bauran pemasaran setelah produk dan merupakan satu-satunya unsur dalam bauran pemasaran yang menghasilkan pendapatan penjualan, sedangkan unsur-unsur lainnya merupakan pengeluaran biaya saja. Keputusan-keputusan mengenai harga mencakup tingkat harga, potongan harga, keringanan periode pemasaran, dan rencana 
iklan yang dibuat oleh produsen. Sedangkan Swasta (2009), harga adalah jumlah uang (ditambah beberapa produk kalau mungkin yang dibutuhkan untuk dapat sejumlah kombinasi produk dan pelayanannya.

\section{Indikator Harga}

Menurut Kotler (2007), indikator harga diantaranya:

1. Keterjangkauan harga

2. Kesesuaian harga dengan kualitas produk

3. Kesesuaian harga dengan manfaat

4. Daya saing harga

5. Harga mempengaruhi daya beli konsumen

6. Harga dapat mempengaruhi konsumen dalam mengambil keputusan

\section{Promosi}

Promosi adalah sejenis komunikasi yang memberi penjelasan yang meyakinkan calon konsumen tentang barang dan jasa (Alma, 2010). Selanjutnya Swastha (2009) menjelaskan bahwa promosi adalah arus informasi atau persuasi satu arah yang dibuat untuk mengarahkan seseorang atau organisasi kepada tindakan yang menciptakan pertukaran dalam pemasaran.

\section{Indikator Promosi}

Alma (2010) menyatakan bahwa indikator promosi terdiri dari:

1. Pemasangan papan reklame

2. Penggunaan iklan di media massa

3. Penggunaan brosur sebagai media informasi

4. Pameran-pameran

5. Penyampaian informasi oleh karyawan

6. Ketepatan waktu untuk berpromosi

\section{Keputusan Pembelian}

Kotler dan Amstrong (2008) menyatakan bahwa keputusan pembelian (purchase decision) konsumen adalah membeli merek yang paling disukai, tetapi dua faktor bisa berada antara niat pembelian dan keputusan pembelian. Sedangkan Sciffman dan Kanuk (2009) mendefinisikan bahwa keputusan pembelian adalah pemilihan dari dua atau lebih alternatif pilihan dalam melakukan pembelian.

\section{Tahap Keputusan Pembelian}

Menurut Kotler dan Amstrong (2008), proses keputusan pembelian meliputi:

1. Pengenalan kebutuhan 
Tahap pertama proses keputusan pembelian dimana konsumen menyadari suatu masalah atau kebutuhan. Kebutuhan dapat dipicu oleh rangsangan internal etika salah satu kebutuhan seseorang timbul seperti rasa lapar dan haus.

2. Pencarian informasi

Tahap proses keputusan pembelian dimana konsumen mencari informasi labih banyak konsumen mungkin hanya memperbesar perhatian atau melakukan pencarian informasi secara aktif.

3. Evaluasi alternatif

Tahap proses keputusan pembelian dimana konsumen menggunakan informasi untuk mengevaluasi alternatif dalam sekelompok pilihan

4. Keputusan pembelian

Keputusan pembelian tentang merek mana yang dibeli

5. Perilaku pasca pembelian

Tahap proses keputusan pembelian di mana konsumen mengambil tindakan selanjutnya setelah pembelian, berdasarkan kepuasan atau ketidakpuasan.

\section{Hipotesis}

Hipotesis dalam penelitian ini adalah:

1. Produk, harga dan promosi secara parsial berpengaruh signifikan terhadap keputusan pembelian rumah pada Green Avina Birem Puntong Langsa Baro.

2. Produk, harga dan promosi secara simultan berpengaruh signifikan terhadap keputusan pembelian rumah pada Green Avina Birem Puntong Langsa Baro.

\section{METODE PENELITIAN}

\section{Jenis dan Sumber Data}

1. Jenis data dibagi menjadi dua, yaitu:

a. Data kualitatif yaitu data yang tidak berbentuk angka, data kualitatif mempunyai ciri tidak bisa dilakukan operasi matematika, seperti penambahan, pengurangan, perkalian dan pembagian (Situmorang dan Lufti, 2014).Data kualitatif pada penelitian ini berupa teori-teori dan gambaran perumahan Green Avina.

b. Data Kuantitatif yaitu data yang berbentuk angka (Situmorang dan Lufti, 2014). Data ini terbagi menjadi data yang diperoleh dengan cara angka yaitu jumlah konsumen dan data tanggapan responden yang di ukur dengan skala likert.

2. Sumber data pada penelitian ini dibagi menjadi dua sumber yaitu:

a. Data Primer yaitu data yang dikumpulkan sendiri oleh perorangan/suatu organisasi secara langsung dari objek yang diteliti dan untuk kepentingan studi yang bersangkutan yang dapat berupa interviu, observasi (Situmorang dan Lufti, 2014). Data primer diperoleh dengan cara 
melakukan penelitian langsung pada objek penelitian yaitu konsumen yang membeli perumahan Green Avina dengan melakukan wawancara, observasi dan memberikan kuesioner.

b. Data sekunder yaitu data yang diperoleh/dikumpulkan dan disatukan oleh studi-studi sebelumnya atau yang diterbitkan oleh berbagai instansi lain (Situmorang dan Lufti, 2014). Data sekunder diperoleh dari buku-buku milik sendiri dan dari perpustakaan Universitas Samudra dan jurnal serta tesis yang berhubungan dengan penelitian ini.

\section{Populasi dan Sampel}

Populasi pada penelitian ini adalah konsumen yang membeli rumah pada Green Avina Birem Puntong dengan Jumlah Rumah tahap awal dan siap huni sebanyak 120 rumah dan saat ini yang telah dihuni sebanyak 53 unit. Penentuan sampel pada penelitian ini menggunakan non probability sampling dengan tehnik sampling jenuh yaitu pengambilan populasi secara keseluruhan untuk dijadikan sampel. Dalam penelitian ini yang diambil menjadi sampel adalah sebanyak 53 orang dari 53 unit yang telah menghuni di perumahan Green Avina Birem Puntong.

\section{Metode Pengumpulan Data}

\section{Penelitian Lapangan}

a. Observasi sebagai tehnik pengumpulan data sebagai ciri yang spesifik bila dibandingkan dengan tehnik yang lain yaitu wawancara dan kuesioner (Sugiyono 2010). Observasi dilakukan untuk mendapatkan data lapangan dengan melihat langsung perumahan Green Avina Residen di Birem Puntong Kecamatan Langsa Baro.

b. Wawancara digunakan sebagai tehnik pengumpulan data apabila peneliti ingin melakukan studi pendahuluan untuk menemukan masalah yang harus di teliti dan juga apabila peneliti ingin mengetahui hal-hal dari responden yang lebih mendalam dan jumlah respondennya sedikit atau kecil (Sugiyono 2010). Wawancara dilakukan langsung dengan konsumen perumahan Green Avina di Birem Puntong Kecamatan Langsa Baro serta dengan pihak perusahaan perumahan Green Avina.

c. Kuisioner merupakan tehnik pengumpulan data yang dilakukan dengan cara memberi seperangkat pertanyaan atau pernyataan tertulis kepada responden untuk dijawabnya (Sugiyono, 2010). Pernyataan variabel pada kuisioner dimasukkan ke dalam skala Likert skor 1-5 dengan kriteria sebagai berikut:

$\begin{array}{lll}\text { Sangat setuju } & \text { SS } & \text { bernilai 5 } \\ \text { Setuju } & \text { S } & \text { bernilai 4 } \\ \text { Netral } & \text { N } & \text { bernilai 3 } \\ \text { Tidak setuju } & \text { TS } & \text { bernilai 2 } \\ \text { Sangat tidak setuju } & \text { STS } & \text { bernilai 1 }\end{array}$




\section{Penelitian Kepustakaan}

Arikunto (2010) menyatakan bahwa kepustakaan atau literatur studi adalah sumber pengumpulan informasi dari paper, dokumen, buku-buku, majalah atau bahan tertulis lainnya, baik teori, laporan penelitian atau penemuan sebelumnya (findings). Pada penelitian ini pengumpulan data sekunder dilakukan dengan membaca buku-buku milik sendiri dan dari perpustakaan Universitas Samudra, jurnal serta tesis yang berhubungan dengan penelitian ini.

\section{Metode Analisis Data}

Menganalisis data pada penelitian ini menggunakan regresi linier berganda yang bertujuan untuk mengetahui pengaruh produk, harga dan pomosi terhadap keputusan pembelian rumah pada Green Avina di Birem Puntong Kecamatan Langsa Baro. Persamaan regresi linier berganda yang digunakan adalah sebagai berikut:

$\mathrm{Y}=\mathrm{a}+\mathrm{b}_{1} \mathrm{X}_{1}+\mathrm{b}_{2} \mathrm{X}_{2}+\mathrm{b}_{3} \mathrm{X}_{3}$

Keterangan:

$\begin{array}{ll}\mathrm{Y} & =\text { Keputusan Pembelian } \\ \mathrm{a} & =\text { Konstanta } \\ \mathrm{X}_{1} & =\text { Produk } \\ \mathrm{X}_{2} & =\text { Harga } \\ \mathrm{X}_{3} & =\text { Promosi } \\ \mathrm{b}_{1}, \mathrm{~b}_{2}, \mathrm{~b}_{3} & =\text { Koefisien regresi }\end{array}$

\section{HASIL DAN PEMBAHASAN}

\section{Persamaan Regresi Linier Berganda}

Pengaruh produk, harga dan promosi terhadap keputusan pembelian rumah pada Green Acina Birem Puntong dapat diketahui dari tanggapan responden. Tanggapan tersebut dianalisis secara statistik dengan menggunakan persamaan regresi linier berganda dan dihitung dengan program Statistical Product Social of Science (SPSS) versi 20.0. Hasil perhitungan dapat diketahui pada Tabel 1 berikut ini.

Tabel 1. Hasil Analisis Statistik

\begin{tabular}{|c|c|c|c|c|}
\hline Variabel & & $\mathrm{B}$ & $\mathrm{t}$ & Sig. $\mathrm{t}$ \\
\hline Konstanta & & 0,933 & 1,750 & 0,086 \\
\hline Produk & & 0,284 & 2,102 & 0,041 \\
\hline Harga & & 0,265 & 2,011 & 0,049 \\
\hline Promosi & & 0,246 & 2,612 & 0,012 \\
\hline R Square & $=$ & 0,456 & & \\
\hline Adjusted R Square & $=$ & 0,423 & & \\
\hline $\mathrm{F}$ & $=$ & 13,686 & & \\
\hline Sig. F & $=$ & 0,000 & & \\
\hline
\end{tabular}


Berdasarkan Tabel 1 maka dapat dibuat persamaan sebagai berikut:

$$
\mathrm{Y}=0,933+0,284 \mathrm{X}_{1}+0,265 \mathrm{X}_{2}+0,246 \mathrm{X}_{3}
$$

Berdasarkan persamaan di atas dapat dijelaskan:

1. Konstanta sebesar 0,933 adalah keputusan pembelian sebelum dipengaruhi oleh variabel produk, harga dan promosi.

2. Koefisien regresi sebesar $0,284 \mathrm{X}_{1}$, menunjukkan bahwa produk berpengaruh positif terhadap keputusan pembelian dan bila produk meningkat satu satuan maka akan meningkatkan keputusan pembelian sebesar 0,284 dengan asumsi variabel harga dan promosi tetap.

3. Koefisien regresi sebesar $0,265 \mathrm{X}_{2}$, menunjukkan bahwa harga berpengaruh positif terhadap keputusan pembelian dan bila harga meningkat satu satuan maka akan meningkatkan keputusan pembelian sebesar 0,265 dengan asumsi variabel produk dan promosi tetap.

4. Koefisien regresi sebesar $0,246 \mathrm{X}_{3}$, menunjukkan bahwa promosi berpengaruh positif terhadap keputusan pembelian dan bila keputusan pembelian meningkat satu satuan maka akan meningkatkan keputusan pembelian sebesar 0,246 dengan asumsi variabel produk dan harga tetap.

\section{Hasil Uji Koefisien Determinasi $\left(\mathbf{R}^{2}\right)$}

Berdasarkan Tabel 1 dapat diketahui nilai koefisien determinasi $\left(\mathrm{R}^{2}\right)$ menggunakan adjusted $R$ Square karena variabel bebas lebih dari 2 variabel dan adjusted $R$ Square sebesar 0,423 atau 42,3\% variabel produk, promosi dan harga memberikan pengaruh terhadap keputusan pembelian rumah pada Green Avina di Birem Puntong Langsa Baro. Kemudian sisanya sebesar 57,7\% dipengaruhi variabel lain yang tidak masuk dalam penelitian ini seperti lokasi, dan fasilitas.

\section{Pembuktian Hipotesis}

\section{Hasil Uji t}

Uji $\mathrm{t}$ (uji secara parsial) diketahui dari $\mathrm{t}_{\text {sig }}$ yang dapat dilihat pada Tabel 1 dan dibandingkan dengan nilai $\alpha 5 \%(0,05)$, dan hasil pengujian sebagai berikut:

1. Pada variabel produk $\mathrm{t}_{\mathrm{sig}}<\alpha 5 \%(0,041<0,05)$, dapat dinyatakan bahwa produk berpengaruh signifikan terhadap keputusan pembelian rumah pada Green Avina Birem Puntong Langsa Baro dan hipotesis pada penelitian ini dapat diterima.

2. Pada variabel harga $\mathrm{t}_{\text {sig }}<\alpha 5 \%(0,049<0,05)$, dapat dinyatakan bahwa harga berpengaruh signifikan terhadap keputusan pembelian rumah pada Green Avina Birem Puntong Langsa Baro dan hipotesis pada penelitian ini dapat diterima.

3. Pada variabel promosi $\mathrm{t}_{\text {sig }}<\alpha 5 \%(0,012<0,05)$, dapat dinyatakan bahwa promosi berpengaruh signifikan terhadap keputusan pembelian rumah pada Green Avina Birem Puntong Langsa Baro dan hipotesis pada penelitian ini dapat diterima. 


\section{Hasil Uji F}

Berdasarkan Tabel 1 dapat diketahui uji $\mathrm{F}$ diperoleh $\mathrm{F}_{\text {sig }}<5 \%(0,000<0,05)$, maka dapat dinyatakan secara simultan variabel produk, harga dan promosi berpengaruh signifikan terhadap keputusan pembelian rumah pada Green Avina Birem Puntong Langsa Baro. Dengan demikian hipotesis yang menyatakan produk, harga dan promosi secara simultan berpengaruh signifikan terhadap keputusan pembelian rumah pada Green Avina Birem Puntong Langsa Baro dapat diterima.

\section{KESIMPULAN DAN SARAN}

\section{Kesimpulan}

Berdasarkan hasil penelitian yang dilakukan dapat ditarik kesimpulan penelitian sebagai berikut:

1. Hasil persamaan regresi linier berganda diperoleh bahwa produk, harga dan promosi berpengaruh positif terhadap keputusan pembelian rumah pada Green Avina Birem Puntong.

2. Hasil uji keofisien determinasi $\left(\mathrm{R}^{2}\right)$ sebesar $42,3 \%$ variabel produk, promosi dan harga memberikan pengaruh terhadap keputusan pembelian rumah pada Green Avina di Birem Puntong Langsa Baro dan sisanya sebesar $57,7 \%$ dipengaruhi variabel lain yang tidak masuk dalam penelitian ini seperti lokasi dan fasilitas.

3. Hasil uji t untuk variabel produk berpengaruh signifikan terhadap keputusan pembelian rumah pada Green Avina Birem Puntong Langsa Baro. Pada variabel harga berpengaruh signifikan terhadap keputusan pembelian rumah pada Green Avina Birem Puntong Langsa Baro. Variabel promosi berpengaruh signifikan terhadap keputusan pembelian rumah pada Green Avina Birem Puntong Langsa Baro.

4. Hasil uji F, secara simultan produk, harga dan promosi berpengaruh signifikan terhadap keputusan pembelian rumah pada Green Avina Birem Puntong Langsa Baro.

\section{Saran}

Berdasarkan hasil penelitian dapat di sarankan:

1. Untuk meningkatkan keputusan pembelian konsumen, PT. Avina Semesta Raya dapat menyediakan rumah dengan berbagai ukuran, kemudian desain rumah yang lebih menarik.

2. Harga produk perumahan sebaiknya diberikan diskon kepada pembeli yang membeli tunai.

3. Promosi yang dilakukan melalui brosur sebaiknya ditambah lagi melalui radio dan surat kabar, sehingga informasi mudah didapatkan oleh calon konsumen.

4. Bagi peneliti selanjutnya dapat menambahkan variabel lain seperti lokasi dan fasilitas.

\section{REFERENSI}

Alma, Buchari. 2010. Manajemen pemasaran. Yogyakarta: Andi. Arikunto, Suharsimi. 2010. Prosedur Penelitian Suatu Pendekatan Praktik. Jakarta: Rineka Cipta. 
Kotler, Philip. 2007. Manajemen Pemasaran: Analisa Implementasi Perencanaan dan Kontrol. Jakarta: PT. Indeks. dan Kevin Lane Keller. 2007. Manajemen Pemasaran. Jakarta: PT Indeks. dan Gary Amstrong. 2008. Prinsip-prinsip Pemasaran. Jakarta: Erlangga.

Schiffman, Leon G dan Kanuk, Leslie Lazar. 2009. Perilaku Konsumen. Alih Bahasa Zulkifi Kasip. Jakarta: PT Indeks Group Gramedia.

Situmorang, Syafrizal Helmi dan Muslich Lufti. 2014. Analisis Data untuk Riset Manajemen dan Bisnis. Medan: USU Press.

Sugiyono. 2010. Metode Penelitian Bisnis. Bandung: Alfabeta.

Swastha, Basu. 2009. Azas-azasMarketing. Yogyakarta: Liberty.

Tjiptono, Fandy. 2008. Strategi Pemasaran. Edisi III. Yogyakarta: Andi. 